\title{
30 LAT STUDIÓW HISTORYCZNYCH W BIAEYMSTOKU. \\ MIEDZYNARODOWA KONFERENCJA NAUKOWA - „GRANICE I POGRANICZA” BIAŁYSTOK 15-17 X 1998
}

30-lecie uniwersyteckich studiów historycznych w Białymstoku stało się okazją do zorganizowania przez Instytut Historii międzynarodowej konferencji. Jej hasło "Granice i pogranicza. Historia codzienności i doświadczeń" odpowiadało specyfice regionu i podstawowemu profilowi badań sporej części historyków białostockich, ale także wkomponowywało się w popularny w ostatnich latach obszar zainteresowań leżący na przecięciu wielu dyscyplin. Szeroka formuła, nie wskazująca na żadne konkretne pogranicze, epokę czy aspekt problemu, spotkała się z dużym odzewem. Temat zainteresowal historyków badających dzieje polityczne, gospodarkę, kulturę, wojskowość, ale także językoznawców, badaczy literatury i pedagogów. Chęć czynnego uczestnictwa w jubileuszowej konferencji zgłosiła blisko połowa pracowników Instytutu Historii Uniwersytetu w Białymstoku, pracownicy zaprzyjaźnionych jednostek tej uczelni i liczna grupa naukowców spoza Białegostoku. Goszczono przedstawicieli polskich ośrodków uniwersyteckich, głównie tych leżących na terenach przygranicznych, a więc specjalizujących się w badaniach tego typu - Wrocławia, Ka towic, Opola, Gdańska, Szczecina, Lublina. Przy jechali do Białegostoku też goście $z$ innych polskich uczelni i instytucji prowadzących badania historyczne: WSP w Rzeszowie i Bydgoszczy, Niemieckiego Instytutu Historycznego z Warszawy i kilka osób samodzielnie prowadzących pracę naukową. Co szczególnie ważne, przyjechało też kilkunastu gości z zagranicy, reprezentujących cztery kraje. Najliczniejszą grupę stanowili Białorusini z Grodna, Mińska i Mohylewa, szczycono się uczestnictwem przedstawicieli paryskiej Sorbony, goszczono naukowców z Wilna i Rygi. 
Zaplanowane początkowo na dwa dni obrady, ze względu na duże zainteresowanie zostały wydłużone i trwały od 15 do 17 października 1998 roku. W trakcie konferencji wygłoszono 69 referatów, z czego 22 przygotowali pracownicy IH UwB, 6 - inni pracownicy tej uczelni i 41 - goście, w tym 14 -zagraniczni. Warto zaznaczyć, że część tej ostatniej grupy referowała w języku polskim, a prawie wszyscy posługiwali się nim w rozmowach kuluarowych, co spotkało się z uznaniem i ciepłym przyjęciem.

Konferencja otwarta została 15 października w auli Wydziału Humanistycznego przez J.M. Rektora Uniwersytetu w Białymstoku prof. dr. hab. Adama Jamroza i Dyrektora Instytutu Historii prof. dr hab. Barbarę Stępniewską-Holzer. W uroczystości uczestniczyli prezydent Białegostoku Krzysztof Jurgiel, wojewoda łomżyński Sławomir Zgrzywa (absolwent instytutu - jubilata), przedstawiciele wojewody białostockiego oraz zaprzy jaźnionych placówek naukowych i oświatowych Białegostoku. Obrady plenarne zainaugurowane zostały przez prof. Andrzeja Chodubskiego (Gdańsk), który wygłosił referat pt. Cywilizacyjna interpretacja kresów. W tej turze uczestniczyli także: prof. Daniel Grinberg (Białystok), który mówił o idei pogranicza w historiografii, prof. Daniel Tollet (Paryż) referu jący zagadnienie przywrócenia katolicyzmu w Mołdawii za czasów Jana III Sobieskiego i prof. Algis Kasperavičius, który opowiadał o spojrzeniu z Kowna na mieszkańców Wileńszczyzny w latach ostatniej wojny.

Ze względu na liczne grono uczestników dalsze obrady odbywały się z podziałem na sekcje. Referaty przedstawiane w sekcji I dotyczyły głównie problemów mniejszości narodowych i religijnych zamieszkujących tereny Polski, obejmując okres od średniowiecza do dnia dzisiejszego. Dyskutowano między innymi o Kozakach, Tatarach i pograniczu polsko-ruskim w dobie Rzeczypospolitej szlacheckiej, o stosunkach z Litwinami, o sytuacji narodowościowej na Śląsku, Mazurach, Pomorzu w XIX•XX wieku. Zastanawiano się wspólnie nad kryteriami podziałów etniczno-narodowych, definiowaniem świadomości narodowej na pograniczach, polityką władz państwowych wobec mniejszości i stosunkiem Polaków do innych narodowości.

Sekcja II zajmowała się zagadnieniami walki o granice, ich wytyczaniem, skupiając się na aspektach politycznych i militarnych. Duża grupa referatów dotyczyła formowania się granic w Europie Wschodniej po I wojnie światowej i ukształtowanych wówczas stosunków politycznych między Polską a jej wschodnimi sąsiadami. Część referentów omawiała natomiast problematykę stosunków politycznych i walki zbrojnej na kresach północno-wschodnich Polski oraz stosunków narodowościowych na ziemiach polskich w okresie 
II wojny światowej. W ramach obrad tej sekcji poruszano też tematy z zakresu historiografii polskiej i białoruskiej.

Obrady sekcji III poświęcone były problemom społecznym, kulturowym i ekonomicznym terenów przygranicznych. Dyskutowano tu na temat szkolnictwa na pograniczach, przeszłości gospodarczej terenów wschodnich dawnej Rzeczy pospolitej, zastanawiano się nad mentalnością, świadomością społeczeństw pograniczy, stereotypami dotyczącymi innych narodów. W ramach tej sekcji referowali też poloniści, opowiadając o przedstawieniu kresów w beletrystyce, o literackiej wizji społeczeństwa żyjącego na styku kultur.

Wobec zaprezentowania przez historyków z różnych ośrodków problematyki wszystkich pograniczy Polski, samoistnie nasunęły się porównania. Ciekawe wnioski jakie wyciągano, wskazujące na wiele podobieństw, doprowadziły do postulatu przeprowadzenia badań komparatystycznych terenów nadgranicznych.

Ważnym i pouczającym doświadczeniem była możliwość skonfrontowania efektów badań i poglądów polskich historyków z ustaleniami i wizją problematyki wspólnych pograniczy reprezentowaną przez naukowców białoruskich, litewskich, łotewskich. Okazało się, że istnieją spore różnice w interpretacji faktów historycznych, nazewnictwie. Nie uniemożliwiają one jednak dyskusji i życzliwej wymiany doświadczeń i poglądów, która może poprawić stan badań i dopomóc w obiektywnym przedstawieniu przeszłości.

Rocznicowy charakter konferencji podkreśliło uroczyste spotkanie, które urządzono pierwszego wieczoru. Obok uczestników konferencji zaproszono nań dawnych pracowników Instytutu Historii, osoby z nim współpracujące oraz gości honorowych - wicewojewodę białostockiego Józefa Klima (także absolwenta białostockiej historii) i rektora UwB. W części oficjalnej przypomniano 30-letnią historię studiów historycznych w Białymstoku i uhonorowano osoby, których wkład w ich budowę i działalność był szczególnie duży Ztota (prof. prof. Andrzej Wyrobisz, Adam Manikowski, Henryk Ruciński) i Srebrna (dr hab. Cezary Kuklo, dr dr Jan Jerzy Milewski i Jan Trynkowski) Odznaka Zastużony Biatostocczyźnie. Wszyscy dawni i obecni pracownicy IH otrzymali piękne medale pamiątkowe, wybite specjalnie $z$ tej okazji. Część nieoficjalna spotkania była okazją do snucia wspomnień z dawnych lat instytutu.

Obrady zakończyły się w południe 17 października, kiedy to podsumowania konferencji dokonał kierujący jej organizacją dr Jan Trynkowski. Pozytywnie oceniając plon prac zapowiedział kolejne spotkania o podobnym charakterze, niekoniecznie organizowane $z$ okazji okrągłych rocznic. 